\title{
Resenha
}

CARNEIRO, Sandra de Sá. A pé e com fé: brasileiros no Caminho de Santiago. São Paulo: Attar, 2007

\section{A FÉ POR MEIO DO PÉ: O BRASIL EM SANTIAGO}

A peregrinação é tema do livro A pé e com fé: brasileiros no Caminho de Santiago. A pesquisa tem como foco as experiências de peregrinos brasileiros no Caminho de Santiago de Compostela, noroeste da Espanha. De autoria de Sandra de Sá Carneiro, professora de Antropologia do Departamento de Ciências Sociais da UERJ, a obra é uma referência para o estudo do Caminho e das práticas religiosas em tela. $\mathrm{O}$ trecho de um poema lançado na sua apresentação logo expressa uma ideia de seu problema científico:

Peregrino, quién te llama?

Qué fuerza oculta te atrae? [...]

La fuerza que a mi me empuja

No sé ni explicarla ni yo.

Sólo El Arriba lo sabe!

O sentido da peregrinação é apurado pelo que o peregrino escuta, fala e faz antes, durante e depois da experiência. As forças que atraem o peregrino são problematizadas pela professora Sandra Carneiro a partir da interpretação de depoimentos sobre os sentidos e os significados do percurso e da experiência em termos de (re)construção da vida, do mundo e da realidade pessoal e coletiva. A pesquisadora é uma daquelas que se faz presente no campo, e daí refaz os seus rumos teórico-metodológicos.

A peregrinação é abordada como um ritual performático. Perpassando por variadas perspectivas, tempos e civilizações, a peregrinação e o peregrino são compreendidos como construções sociais. O "ser peregrino" é denotado como uma questão de ethos e visão de mundo. $\mathrm{O}$ estudo considera o estado de liminaridade como uma expressão da experiência humana de quem peregrina, aparecendo imbricado num sistema simbólico de construção do mundo, como faz pensar Geertz em A interpretação das culturas. 
O leitor é situado no marco dos acontecimentos influenciadores do nascimento da multissecular peregrinação. A constituição do mito, da tradição e da singularidade de Compostela é recontada ao se considerar "o que se fala quando se fala da origem da peregrinação a Santiago" (CARNEIRO, 2007, p. 47). Para além da dimensão religiosa, o Caminho é desvelado como um catalisador de culturas, transmissor de ideias e promotor de encontros, o que pode ser averiguado na literatura, na música, na arte e na história que se refere à região, bem como na sua prosperidade econômica e no que toca ao turismo - tema analisado nas suas interfaces com a peregrinação.

Um perfil geral dos peregrinos brasileiros e as suas expectativas são postas em relevo. O livro $O$ Diário de um Mago, de Paulo Coelho, é apontado como um dos principais responsáveis pelo interesse dos brasileiros pelo Caminho de Santiago. A professora Sandra Carneiro fundamenta uma crítica sobre critérios de definição da "categoria" peregrinos para a Igreja, sobretudo, por não levar em conta as representações dos próprios peregrinos.

O chão de estrelas, o caminho, é tido como um campo minado de significações, como bem sintetiza uma peregrina: "fazer o Caminho é descobrir o mundo com o nosso mundo nas costas" (Ibidem, p. 121). Naquele contexto, a peregrinação a pé é valorizada quase sempre como uma questão de honra e princípio, comportando uma complexidade de sentidos e finalidades. Para interpretar a intricada realidade, estabelece-se uma espécie de gramática da peregrinação, atentando para as múltiplas linguagens sobre o Caminho. As tensões e communitas (baseada em Turner, em $O$ processo ritual: estrutura e anti-estrutura) são descritas com um nível que acaba envolvendo - não raro, é como se nos percebêssemos a caminho.

Como o fenômeno da peregrinação a Santiago ganha visibilidade no contexto brasileiro? Essa é uma questão que tem a análise focada na divulgação e difusão do Caminho e no entendimento da estrutura significativa da experiência dos peregrinos entrevistados. Em tal quadro, onde os significados andam juntos com os peregrinos, a peregrinação pode ser traduzida pelos arranjos que permitem tornar a vida mais digna de ser vivida.

A obra trata o ato de peregrinar a partir da "geografia do caminho" e conduz o seu leitor por tempos e espaços sagrados. Com efeito, o espírito e a identidade do peregrino são entendidos por meio de uma geograficidade que 
relaciona a ida, a experiência e o retorno, fundamentando um modo significativo de habitar a Terra.

Do caminho, da trajetória, da vida, a epígrafe utilizada no início do livro, dá o tom final desta resenha...

É inútil querer procurar encontrar caminho e querer começar, já sabendo que a voz diz pouco, já começando por ser despessoal.

Pois existe a trajetória, e a trajetória não é um modo de ir. A trajetória somos nós mesmos.

Em matéria de viver nunca se pode chegar antes.

Clarice Lispector, A Paixão Segundo G.H.

Resenha por José Arilson Xavier de Souza

Universidade do Estado do Rio de Janeiro. 